\title{
Placemaking Ruang Jalan Koridor Komersial Kota SURAKARTA
}

\author{
Patrani Victorya T, Rizon Pamardhi Utomo, Galing Yudana \\ Program Studi Perencanaan Wilayah dan Kota, \\ Jurusan Arsitektur, Fakultas Teknik \\ Universitas Sebelas Maret, Surakarta \\ email: vpatrani @gmail.com
}

\begin{abstract}
Placemaking is an attempt to form a space into a place that has meaning for its users. The concept of placemaking motivated by all the existing space in the city, both of street and public space that can have meaning as a place where it will occur at the site of social interaction and communication among users of space. Street in a commercial corridor in Surakarta is an important infrastructure to support commercial activities, but the function of the cause of street becomes passive and less interested in the community to conduct joint activities in that space. This shows that street is still not able to accommodate other activities simultaneously and social interactions that lead to placemaking. The problem in this study is whether placemaking already happening commercial corridor street and how much street placemaking commercial corridors. Scope of this research include the way to commercial corridor Surakarta with sample corridor commercial there are six. The method used to determine how much placemaking happened in the commercial corridor of street to be reviewed based on variables derived from placemaking elements, namely comfort and image, accessibility and linkage, uses and activities, as well as sosialibility. The research proves that placemaking has occurred in the commercial corridor of street in Surakarta. But the realization of placemaking in commercial corridor street is still weak, as indicated by the lack of availability of means of supporting activities in the form sitting group. Pedestrian walkway used for informal traders activity and social interaction has not been evenly occurs in the entirety of the commercial corridors in the city of Surakarta.
\end{abstract}

Keywords: placemaking, street, commercial corridor.

\section{PENDAHULUAN}

Placemaking adalah cara di mana semua manusia mengubah tempat mereka, menemukan diri mereka ke tempat di mana mereka tinggal (Schneekloth, L. dan Shibley, R.G., 1995). Dalam placemaking, Dovey (1985) mengungkapkan bahwa place menunjukkan hubungan antara manusia dengan sebuah makna. Place tidak hanya memiliki pandangan secara fisik saja namun juga ditekankan pada pengalaman ruang yang dirasakan oleh penggunanya. Empat kriteria utama placemaking adalah sociability, uses and activities, access and linkage, dan comfort and image (Bohl 2002).

Kegiatan perdagangan di Kota Surakarta pada umumnya mengikuti jaringan jalan sehingga membentuk koridor komersial. Ruang jalan koridor komersial yang ada di Kota Surakarta pada umumnya masih banyak digunakan untuk kegiatan perparkiran. Parkir on street merupakan tipe parkir yang menggunakan bahu jalan dan menyebabkan berkurangnya lebar badan jalan untuk fungsi sirkulasi. Kondisi tersebut menyebabkan ruang jalan koridor komersial menjadi cukup padat dengan kendaraan bermotor, sehingga kenyamanan untuk ruang jalannya pun berkurang.

Ruang jalan koridor komersial seharusnya dapat menampung kegiatan kendaraan bermotor sebagai sirkulasi dan kegiatan pengguna ruang pejalan kaki. Koridor komersial di Kota Surakarta tidak semuanya memiliki ruang jalan yang dapat menampung kedua pengguna tersebut. Fenomena yang terjadi adalah banyak pengguna jalan justru berjalan di teras dari bangunan komersial karena keterbatasan trotoar pejalan kaki dan beberapa pengguna juga berlindung pada teras 
bangunan komersial karena kurangnya ruang yang dapat digunakan untuk melakukan interaksi sosial pada ruang jalan.

Kondisi lain yang terjadi pada ruang jalan koridor komersial adalah ruang jalan koridor komersial memiliki kehidupan jalan yang aktif pada saat pagi sampai sore hari saja. Beberapa koridor komersial memiliki kegiatan komersial dari pagi hingga sore hari, sehingga berdampak terhadap kondisi ruang jalan yang menjadi sepi pada malam hari. Proses penciptaan tempat melalui interaksi sosial di ruang jalan koridor komersial masih belum optimal karena belum tersedianya sarana penunjang interaksi sosial yang berupa bangku atau tempat duduk.

Beberapa fenomena lain yang ada di Kota Surakarta terkait dengan placemaking ruang jalan koridor komersial adalah ruang jalan masih menjadi ruang yang pasif dan belum mampu menjadi ruang yang dapat menghadirkan kegiatan lain. Hal tersebut menyebabkan proses penciptaan ruang menjadi tempat pada ruang jalan koridor komersial belum begitu terlihat. Tujuan dari penelitian ini adalah untuk mengetahui sudah terjadi placemaking dan besarnya placemaking pada ruang jalan koridor komersial di Kota Surakarta.

\section{METODE}

\subsection{Ruang Lingkup}

Ruang lingkup wilayah penelitian ini mencakup ruang jalan koridor komersial di Kota Surakarta baik yang berada pada pusat kota maupun yang berada di pinggiran kota. Karakteristik dari koridor komersial yang menjadi lingkup penelitian adalah berupa kumpulan bangunan toko dan ritel yang ada di sepanjang jalan. Penelitian ini menggunakan enam sampel koridor komersial yang ada di Kota Surakarta yaitu koridor komersial Jalan Radjiman, koridor komersial Jalan S.Parman, koridor komersial Jalan Piere Tendean, koridor komersial Jalan Yos Sudarso, koridor komersial Jalan Kapten Mulyadi, dan koridor komersial Jalan Urip Sumoharjo.

Indikator yang digunakan dalam penelitian ini sesuai dengan elemen-elemen placemaking yaitu kenyamanan dan identitas, aksesibilitas dan tautan, fungsi dan kegiatan, serta sosialibilitas ( Project for Public Space, 2009).

\subsection{Metode Analisis}

Penelitian ini menggunakan dua metode analisis yaitu analisis deskriptif dan analisis kuantitatif. Teknik analisis yang digunakan pada penelitian ini adalah teknik analisis skoring untuk mendapatkan besarnya placemaking yang terjadi pada ruang jalan koridor komersial di Kota Surakarta. Tujuan dari analisis yang dilakukan adalah agar dapat mencapai dua sasaran dalam penelitian ini yaitu

1. Mengetahui terjadi atau tidak upaya pembentukan tempat (placemaking) pada ruang jalan koridor komersial.

2. Mengetahui besarnya upaya yang telah dilakukan dalam proses mengubah ruang (space)menjadi tempat (place) di ruang jalan koridor komersial.

\section{HASIL DAN PEMBAHASAN \\ 3.1. Analisis Deskriptif Placemaking}

Ruang jalan pada koridor komersial yang menjadi sampel penelitian yaitu koridor komersial Jalan Radjiman, koridor komersial Jalan S.Parman, koridor komersial Jalan Piere Tendean, koridor komersial Jalan Yos Sudarso, koridor komersial Jalan Kapten Mulyadi, dan koridor komersial Jalan Urip Sumoharjo memiliki karakteristik ruang jalan yang berbeda-beda. Secara umum hampir semua koridor perdagangan telah dilengkapi dengan trotoar untuk pejalan kaki. Koridor komersial yang tidak memiliki trotoar yaitu koridor komersial S. Parman. Ruang jalan pada koridor komersial yang dilengkapi dengan trotoar pun belum keseluruhan memenuhi dari standar ruang bebas untuk melakukan kegiatan berbelanja. Lima koridor komersial yang memiliki trotoar, hanya satu koridor komersial yang memenuhi standar ruang bebas untuk pejalan kaki, yaitu pada koridor komersial Kapten Mulyadi.

Ruang jalan yang digunakan untuk sirkulasi kendaraan bermotor pada enam koridor komersial memiliki kepadatan lalu lintas yang berbeda-beda. Berdasarkan data lalu lintas terkait dengan derajat kejenuhan jalan, enam koridor komersial ini memiliki nilai derajat kejenuhan lalu lintas yang tinggi. Hal tersebut terjadi karena keterbatasan ruang 
untuk kegiatan komersial sehingga menggunakan ruang jalan. Contohnya adalah trotoar digunakan untuk ruang display pada kegiatan komersial.Sistem perparkiran yang ada pada koridor komersial memiliki sistem parkir on street. Sistem parkir on street ini juga menambah adanya kepadatan lalu lintas.

Sarana yang dapat digunakan di ruang jalan yang berupa tempat duduk merupakan sarana yang dapat menarik pengguna untuk melakukan kegiatan lain pada koridor komersial. Kondisi yang ada pada ruang jalan koridor komersial adalah belum semua koridor komersial memiliki sarana tempat duduk yang mampu menghidupkan ruang jalan. Moda transportasi umum tidak terlepas dari sarana penunjangnya yaitu halte, pada enam koridor komersial tidak semuanya telah difasilitasi dengan halte. Tiga koridor komersial telah memiliki halte sedangkan tiga koridor komersial yang lain tidak memiliki halte. Secara keseluruhan moda transportasi umum yang melayani koridor komersial di Kota Surakarta.

Berdasarkan bahasan dari setiap elemenelemen placemaking pada ruang jalan koridor komersial sudah mengarah pada proses pembentukan tempat (placemaking).

\subsection{Analisis Tingkat Placemaking Ruang Jalan Koridor Komersial}

Pada analisis tingkat placemaking ruang jalan dilakukan skoring pada enam koridor komersial yang telah ditetapkan sebelumnya. Berikut ini merupakan hasil skoring tersbut.

1. Total skor dari tingkat placemaking ruang jalan koridor komersial Jalan Radjiman adalah 6,5 (lihat lampiran 1 tabel Skoring Tingkat Placemaking Ruang Jalan Koridor Komersial Radjiman ) sehingga tingkat placemaking ruang jalan koridor komersial adalah lemah.

2. Total skor dari tingkat placemaking ruang jalan koridor komersial Jalan Kapten Mulyadi adalah 7,5 (lihat lampiran 2 tabel Skoring Tingkat Placemaking Ruang Jalan Koridor Komersial Kapten Mulyadi) sehingga tingkat placemaking ruang jalan koridor komersial adalah sedang.

3. Total skor dari tingkat placemaking ruang jalan koridor komersial Jalan
Piere Tendean adalah 5,25 (lihat lampiran 3 tabel Skoring Tingkat Placemaking Ruang Jalan Koridor Komersial Piere Tendean) sehingga tingkat placemaking ruang jalan koridor komersial adalah lemah.

4. Total skor dari tingkat placemaking ruang jalan koridor komersial Jalan S. Parman adalah 5,8 (lihat lampiran 4 tabel Skoring Tingkat Placemaking Ruang Jalan Koridor Komersial S. Parman) sehingga tingkat placemaking ruang jalan koridor komersial adalah lemah

5. Total skor dari tingkat placemaking ruang jalan koridor komersial Jalan Yos Sudarso adalah 6 (lihat lampiran 5 tabel Skoring Tingkat Placemaking Ruang Jalan Koridor Komersial Yos Sudarso) sehingga tingkat placemaking ruang jalan koridor komersial adalah lemah

6. Total skor dari tingkat placemaking ruang jalan koridor komersial Jalan Urip Sumoharjo adalah 6,8 (lihat lampiran 6 tabel Skoring Tingkat Placemaking Ruang Jalan Koridor Komersial Urip Sumoharjo) sehingga tingkat placemaking ruang jalan koridor komersial adalah sedang.

Berdasarkan hasil skoring dari masingmasing koridor yang menjadi sampel penelitian maka diketahui bahwa ada dua ruang koridor komersial yang mempunyai tingkat placemaking ruang jalan sedang yaitu koridor komersial Jalan Urip Sumoharjo dan koridor komersial Jalan Kapten Mulyadi dan empat koridor komersial lain mempunyai tingkat placemaking ruang jalan lemah yaitu koridor komersial Jalan Piere Tendean, koridor komersial Jalan S.Parman, koridor komersial Jalan Yos Sudarso, dan koridor komersial Jalan Radjiman.

Secara umum teori placemaking membuktikan bahwa pada ruang jalan koridor komersial Kota Surakarta sudah memperlihatkan upaya pembentukan place pada seluruh sampel penelitian. Namun belum secara keseluruhan dari sampel penelitian memiliki tingkat yang baik. Berikut ini merupakan ulasan dari empat elemen placemaking ruang jalan koridor komersial yang ada di Kota Surakarta.

1. Kenyamanan dan Identitas 
Kenyaman dan identitas merupakan sesuatu yang dapat dirasakan oleh pengguna pada ruang tersebut dan memiliki kesan (Weisman,1981). Hasil dari analisis tingkat placemaking ruang jalan koridor komersial memiliki tingkat yang lemah dan sedang. Tingkat kenyamanan dan identitas badan jalan koridor komersial diidentifikasi melalui derajat kejenuhan lalu lintas. Koridor komersial di Kota Surakarta memang belum secara menyeluruh memiliki arus lalu lintas yang selalu lancar pada setiap waktu. Hal tersebut dikarenakan adanya faktor hambatan samping yang berupa parkir on street.

Kenyamanan ruang jalan koridor komersial bagian trotoar pejalan kaki harus memiliki ruang bebas minimal 2,7m (Pedestrian Facilities Guidebook,2004). Trotoar ruang jalan koridor komersial Kota Surakarta masih belum mencapai atau memenuhi standar tersebut.

2. Aksesibilitas dan tautan

Aksesibilitas dan tautan merupakan Merupakan akses pencapaian dan hubungan tempat dengan lingkungan di sekitarnya sehingga mampu membentuk citra tempat. Space akan menjadi place apabila terdapat berbagai jenis transportasi publik, memiliki area istirahat pada suatu kawasan dan terhubung dengan trotoar dan jalan, dan memiliki sistem transit untuk moda transportasi publik

(Project for Public Space, 2009). Setiap ruang jalan di Kota Surakarta mampu memberikan arahan ke lokasi-lokasi yang diharapkan dengan beberapa fasilitas ruang jalan. Badan jalan memiliki peranan penting dalam mencapai tingkat aksesibilitas yang baik. Hal ini dikarenakan badan jalan tersebut merupakan ruang untuk sirkulasi kendaraan. Setiap ruang jalan koridor komersial di Kota Surakarta memiliki lokasi yang cukup strategis meskipun berada di pinggiran. Pelayanan moda transportasi umum yang ada di kota ini telah menjangkau seluruh bagian di Kota Surakarta, baik dari pusat kota maupun menuju ke pinggiran kota.
Fasilitas yang berupa moda transportasi umum ini dapat mempermudah penggunan ruang jalan dari satu koridor komersial ke koridor komersial yang lain. Aksesibilitas dan tautan pada bagian badan jalan mencapai proses perubahan ruang menjadi place atau placemaking sudah kuat. Kelancaran untuk melintasi trotoar bergantung pada lebar ruang bebas yang berasal dari kenyamanan trotoar. Koridor komersial Kota Surakarta memiliki trotoar yang sering digunakan untuk tempat berjualan PKL.

3. Fungsi dan Kegiatan

Fungsi dan kegiatan (Project for Public Space, 2009) merupakan perilaku dalam suatu ruangan secara terus menerus dan terdapat keragaman fungsi pada ruang jalan tersebut selain fungsi utama yaitu fungsi komersial. Bagian ruang jalan yaitu trotoar pada koridor komersial di Kota Surakarta belum secara keseluruhan menunjang fungsi dan kegiatan. Pengguna jalan yang betah pada trotoar membuktikan bahwa pengguna tersebut sudah merasakan place pada trotoar pejalan kaki. Kota Surakarta sendiri masih belum secara merata menyediakan fasilitas trotoar di setiap ruang jalan pada koridor komersial.

Keseluruhan ruang parkir koridor komersial di Kota Surakarta memiliki tipe parkir on street. Keseluruhan ruang parkir koridor komersial di Kota Surakarta memiliki tipe parkir on street. Ruang parkir dengan tipe parkir on street ini memiliki dampak yang baik bagi kemudahan dalam mengakses toko atau retail namun memberikan dampak buruk bagi sirkulasi kendaraan yang ada pada ruang jalan

4. Sosialibilitas

Ruang jalan yang dapat membangkitakan interaksi sosial adalah pada bagian tempat transit. Secara keseluruhan ruang jalan di koridor komersial di Kota Surakarta belum terdapat tempat transit. Tempat transit mendukung proses placemaking ruang jalan. Tempat transit memberikan ruang bagi pengguna ruang jalan untuk dapat 
melakukan kegiatan lain dan merasakan betah pada ruang jalan tersebut. Belum tersedianya tempat transit yang dapat digunakan untuk pengguna ruang jalan menunjukkan bahwa sosialibilitas pada ruang jalan koridor komersial memiliki tingkat lemah.

Secara keseluruhan dari elemenelemen placemaking sudah dibahas dan diulas dengan kondisi yang ada pada ruang jalan koridor komersial. Tingkat placemaking yang lemah menunjukkan bahwa upaya pembentukan placemaking pada ruang jalan di Kota Surakarta masih minimal. Hal yang dirasakan oleh pengguna ruang jalan koridor komersial di Kota Surakarta masih belum mengarah pada makna tempat yang biasa mereka tinggali. Placemaking ruang jalan koridor komersial di Kota Surakarta memiliki tingkat yang lemah, namun sudah terdapat upaya untuk untuk merubah space menjadi place yaitu menyediakan fasilitas transportasi umum yang berupa bus kota dan halte, serta trotoar untuk pejalan kaki

\section{KESIMPULAN}

Penelitian ini membuktikan bahwa placemaking terjadi pada ruang jalan koridor komersial di Kota Surakarta. Hal tersebut dapat ditunjukkan pada kondisi secara fisik memenuhi kriteria pada elemen-elemen placemaking yang menjadi variabel dari penelitian ini. Selain secara fisik, dapat ditunjukkan pula bahwa beberapa pengguna ruang jalan cukup sering melakukan kegiatan lain secara bersamaan pada ruang jalan koridor komersial yang disertai dengan interaksi sosial dengan sesama pengguna ruang jalan.

Penelitian ini juga menjawab tujuan penelitian yaitu mengetahui besarnya placemaking yang terjadi pada ruang jalan koridor komersial di Kota Surakarta. Besarnya placemaking yang terjadi pada ruang jalan koridor komersial Kota Surakarta menunjukkan tingkat yang lemah, yang berarti memiliki upaya pembentukan tempat yang masih minimal.

\section{REFERENSI}

Bohl, Charles C. (2002). Place Making: Developing Town Center, Main Streets and Urban Village. Washington DC: The Urban Institute.

Dovey, K., Downton, P., \& Missingham, G, (Ed). 1985. Place and Placemaking. Melbourne : The Association for People and Physical Environment.

Pedestrian Facilities GuideBook,2004

Project for public Space. http//www.pps.org./info/placemakingtools /issues/commercialize. diakses pada tanggal 20 Desember 2014 pukul 15.08)

Schneekloth, Lynda H. \& Shibley, Robert G. (1995). Placemaking: The Art and Practice of Building Communities. New York: John Wiley \& Sons, Inc

Weisman, J. (1981). Evaluating Architectural Legibility: Way-finding and the Built Environment, Environment and Behavior. 


\section{LAMPIRAN}

Lampiran 1 Skoring Tingkat Placemaking Ruang Jalan Koridor Komersial Radjiman

\begin{tabular}{|c|c|c|c|c|}
\hline No & Variabel & Sub Variabel & Hasil & Skor \\
\hline \multirow{4}{*}{1.} & \multirow{4}{*}{$\begin{array}{l}\text { Kenyamanan dan } \\
\text { Identitas }\end{array}$} & Badan jalan & Derajat Kejenuhan 0,5 - 0,9 & \\
\hline & & Trotoar Pejalan kaki & Ruang bebas pejalan kaki antara $0,5-3,7$ & \\
\hline & & Ruang parkir & Parkir bahu Jalan atau parkir onstreet & \\
\hline & & $\begin{array}{l}\text { Bangunan komersial dan tempat } \\
\text { transit }\end{array}$ & $\begin{array}{l}\text { Rasa betah dari pengguna lebih dari } 60 \\
\text { menit }\end{array}$ & \\
\hline \multirow{3}{*}{2.} & \multirow{3}{*}{$\begin{array}{l}\text { Aksesibilitas dan } \\
\text { Tautan }\end{array}$} & Badan jalan & Dilayani moda transportasi umum & 1 \\
\hline & & Trotoar Pejalan kaki & Trotoar dapat dilintasi secara leluasa & $1 / 3$ \\
\hline & & $\begin{array}{l}\text { Bangunan komersial dan tempat } \\
\text { transit }\end{array}$ & Terdapat sherlter untuk tempat transit & 1 \\
\hline \multirow{4}{*}{3.} & \multirow{4}{*}{$\begin{array}{l}\text { Fungsi dan } \\
\text { Kegiatan }\end{array}$} & Badan jalan & $\begin{array}{l}\text { Sirkulasi yang pada suatu saat terjadi } \\
\text { kemacetan }\end{array}$ & $2 / 4$ \\
\hline & & Trotoar Pejalan kaki & Terdapat gangguan PKL pada trotoar & \\
\hline & & Ruang parkir & Sangat sulit memarkirkan kendaraan & 1 \\
\hline & & $\begin{array}{l}\text { Bangunan komersial dan tempat } \\
\text { transit }\end{array}$ & $\begin{array}{l}\text { Pengunjung kadang melakukan kegiatan } \\
\text { lain }\end{array}$ & $2 / 4$ \\
\hline 4. & Sosialibilitas & $\begin{array}{l}\text { Bangunan komersial dan tempat } \\
\text { transit }\end{array}$ & $\begin{array}{l}\text { Tidak tersedianya ruang yang dapat } \\
\text { digunakan untuk berinteraksi } \\
\text { bangunan komersial maupun tempat } \\
\text { transit. }\end{array}$ & 1 \\
\hline
\end{tabular}

\section{Sumber: AnalisisPenulis,2015}

Lampiran 2 Tabel Skoring Tingkat Placemaking Ruang Jalan Koridor Komersial Kapten Mulyadi

\begin{tabular}{|c|c|c|c|c|}
\hline No & Variabel & Sub Variabel & Hasil & Skor \\
\hline \multirow{4}{*}{1.} & \multirow{4}{*}{$\begin{array}{l}\text { Kenyamanan dan } \\
\text { Identitas }\end{array}$} & Badan jalan & Derajat Kejenuhan 0,5 - 0,9 & $2 / 4$ \\
\hline & & Trotoar Pejalan kaki & Ruang bebas pejalan kaki antara $4 \mathrm{~m}$ & $3 / 4$ \\
\hline & & Ruang parkir & Parkir bahu Jalan & $2 / 4$ \\
\hline & & $\begin{array}{l}\text { Bangunan komersial dan tempat } \\
\text { transit }\end{array}$ & $\begin{array}{l}\text { Rasa betah dari pengguna antara lebih } \\
\text { dari } 60 \text { menit }\end{array}$ & $3 / 4$ \\
\hline \multirow{3}{*}{2.} & \multirow{3}{*}{$\begin{array}{l}\text { Aksesibilitas dan } \\
\text { Tautan }\end{array}$} & Badan jalan & Dilayani moda transportasi umum & 1 \\
\hline & & Trotoar Pejalan kaki & $\begin{array}{l}\text { Trotoar dapat dilintasi secara sangat } \\
\text { leluasa }\end{array}$ & 1 \\
\hline & & $\begin{array}{l}\text { Bangunan komersial dan tempat } \\
\text { transit }\end{array}$ & Terdapat shelter untuk tempat transit & 1 \\
\hline \multirow{4}{*}{3.} & \multirow{4}{*}{$\begin{array}{l}\text { Fungsi dan } \\
\text { Kegiatan }\end{array}$} & Badan jalan & $\begin{array}{l}\text { Sirkulasi yang pada suatu saat terjadi } \\
\text { kemacetan }\end{array}$ & $2 / 4$ \\
\hline & & Trotoar Pejalan kaki & Terdapat PKL pada trotoar & $1 / 4$ \\
\hline & & Ruang parkir & Sangat mudah memarkirkan kendaraan & $3 / 4$ \\
\hline & & $\begin{array}{l}\text { Bangunan komersial dan tempat } \\
\text { transit }\end{array}$ & $\begin{array}{l}\text { Pengunjung sering melakukan kegiatan } \\
\text { lain }\end{array}$ & $3 / 4$ \\
\hline 4. & Sosialibilitas & $\begin{array}{l}\text { Bangunan komersial dan tempat } \\
\text { transit }\end{array}$ & $\begin{array}{l}\text { Tersedia bangku untuk melakukan } \\
\text { interaksi sosial. }\end{array}$ & 3 \\
\hline
\end{tabular}


Lampiran 3 Tabel Skoring Tingkat Placemaking Ruang Jalan Koridor Komersial Piere Tendean

\begin{tabular}{|c|c|c|c|c|}
\hline No & Variabel & Sub Variabel & Hasil & Skor \\
\hline \multirow{4}{*}{1.} & \multirow{4}{*}{$\begin{array}{l}\text { Kenyamanan dan } \\
\text { Identitas }\end{array}$} & Badan jalan & Derajat Kejenuhan 0,5 - 0,9 & $2 / 4$ \\
\hline & & Trotoar Pejalan kaki & Ruang bebas pejalan kaki $0,9 \mathrm{~m}$ & $1 / 4$ \\
\hline & & Ruang parkir & Parkir bahu Jalan atau onstreet & $2 / 4$ \\
\hline & & $\begin{array}{l}\text { Bangunan komersial dan tempat } \\
\text { transit }\end{array}$ & $\begin{array}{l}\text { Rasa betah dari pengguna lebih dari } 60 \\
\text { menit }\end{array}$ & $3 / 4$ \\
\hline \multirow{3}{*}{2.} & \multirow{3}{*}{$\begin{array}{l}\text { Aksesibilitas dan } \\
\text { Tautan }\end{array}$} & Badan jalan & Dilayani moda transportasi umum & 1 \\
\hline & & Trotoar Pejalan kaki & $\begin{array}{l}\text { Trotoar sangat sulit dilintasi secara } \\
\text { leluasa }\end{array}$ & $1 / 3$ \\
\hline & & $\begin{array}{l}\text { Bangunan komersial dan tempat } \\
\text { transit }\end{array}$ & $\begin{array}{l}\text { Tidak terdapat shelter untuk tempat } \\
\text { transit }\end{array}$ & $1 / 3$ \\
\hline \multirow{4}{*}{3.} & \multirow{4}{*}{$\begin{array}{l}\text { Fungsi dan } \\
\text { Kegiatan }\end{array}$} & Badan jalan & $\begin{array}{l}\text { Sirkulasi yang pada suatu saat terjadi } \\
\text { kemacetan }\end{array}$ & $2 / 4$ \\
\hline & & Trotoar Pejalan kaki & Terdapat PKL pada trotoar & $1 / 4$ \\
\hline & & Ruang parkir & Sangat sulit memarkirkan kendaraan & $1 / 4$ \\
\hline & & $\begin{array}{l}\text { Bangunan komersial dan tempat } \\
\text { transit }\end{array}$ & $\begin{array}{l}\text { Pengunjung sering melakukan kegiatan } \\
\text { lain }\end{array}$ & $3 / 4$ \\
\hline 4. & Sosialibilitas & $\begin{array}{l}\text { Bangunan komersial dan tempat } \\
\text { transit }\end{array}$ & $\begin{array}{l}\text { Tidak tersedia bangku untuk melakukan } \\
\text { interaksi sosial. }\end{array}$ & 1 \\
\hline
\end{tabular}

Sumber: Analisis Penulis, 2015

Lampiran 4 Tabel Skoring Tingkat Placemaking Ruang Jalan Koridor Komersial S. Parman

\begin{tabular}{|c|c|c|c|c|}
\hline No & Variabel & Sub Variabel & Hasil & Skor \\
\hline \multirow{4}{*}{1.} & \multirow{4}{*}{$\begin{array}{l}\text { Kenyamanan dan } \\
\text { Identitas }\end{array}$} & Badan jalan & Derajat Kejenuhan 0,5 - 0,9 & $2 / 4$ \\
\hline & & Trotoar Pejalan kaki & Tidak terdapat trotoar & $1 / 4$ \\
\hline & & Ruang parkir & Parkir on street & $1 / 4$ \\
\hline & & $\begin{array}{l}\text { Bangunan komersial dan tempat } \\
\text { transit }\end{array}$ & $\begin{array}{l}\text { Rasa betah dari pengguna ruang jalan } \\
\text { sekitar } 30-60 \text { menit }\end{array}$ & $2 / 4$ \\
\hline \multirow{3}{*}{2.} & \multirow{3}{*}{$\begin{array}{l}\text { Aksesibilitas dan } \\
\text { Tautan }\end{array}$} & Badan jalan & Dilayani moda transportasi umum & 1 \\
\hline & & Trotoar Pejalan kaki & Tidak terdapat trotoar & $1 / 3$ \\
\hline & & $\begin{array}{l}\text { Bangunan komersial dan tempat } \\
\text { transit }\end{array}$ & $\begin{array}{l}\text { Tidak terdapat shelter untuk tempat } \\
\text { transit }\end{array}$ & $1 / 3$ \\
\hline \multirow{4}{*}{3.} & \multirow{4}{*}{$\begin{array}{l}\text { Fungsi dan } \\
\text { Kegiatan }\end{array}$} & Badan jalan & $\begin{array}{l}\text { Sirkulasi yang pada suatu saat terjadi } \\
\text { kemacetan }\end{array}$ & $2 / 4$ \\
\hline & & Trotoar Pejalan kaki & Terdapat PKL pada trotoar & $1 / 4$ \\
\hline & & Ruang parkir & Sangat sulit memarkirkan kendaraan & $1 / 4$ \\
\hline & & $\begin{array}{l}\text { Bangunan komersial dan tempat } \\
\text { transit }\end{array}$ & $\begin{array}{l}\text { Pengunjung sering melakukan kegiatan } \\
\text { lain }\end{array}$ & $3 / 4$ \\
\hline 4. & Sosialibilitas & $\begin{array}{l}\text { Bangunan komersial dan tempat } \\
\text { transit }\end{array}$ & $\begin{array}{l}\text { Tidak tersedia bangku untuk melakukan } \\
\text { interaksi sosial. }\end{array}$ & 1 \\
\hline
\end{tabular}


Lampiran 5 Tabel Skoring Tingkat Placemaking Ruang Jalan Koridor Komersial Yos Sudarso

\begin{tabular}{|c|c|c|c|c|}
\hline No & Variabel & Sub Variabel & Hasil & Skor \\
\hline \multirow{4}{*}{1.} & \multirow{4}{*}{$\begin{array}{l}\text { Kenyamanan dan } \\
\text { Identitas }\end{array}$} & Badan jalan & Derajat Kejenuhan 0,5 - 0,9 & $2 / 4$ \\
\hline & & Trotoar Pejalan kaki & Terdapat trotoar selebar $0,9 \mathrm{~m}$ & $1 / 4$ \\
\hline & & Ruang parkir & Parkir on street & $1 / 4$ \\
\hline & & $\begin{array}{l}\text { Bangunan komersial dan tempat } \\
\text { transit }\end{array}$ & $\begin{array}{l}\text { Rasa betah dari pengguna kurang dari } 30 \\
\text { menit }\end{array}$ & $1 / 4$ \\
\hline \multirow{3}{*}{2.} & \multirow{3}{*}{$\begin{array}{l}\text { Aksesibilitas dan } \\
\text { Tautan }\end{array}$} & Badan jalan & Dilayani moda transportasi umum & 1 \\
\hline & & Trotoar Pejalan kaki & Trotoar kurang leluasa ketika dilintasi & $2 / 3$ \\
\hline & & $\begin{array}{l}\text { Bangunan komersial dan tempat } \\
\text { transit }\end{array}$ & $\begin{array}{l}\text { Tidak terdapat shelter untuk tempat } \\
\text { transit }\end{array}$ & $1 / 3$ \\
\hline \multirow{4}{*}{3.} & \multirow{4}{*}{$\begin{array}{l}\text { Fungsi dan } \\
\text { Kegiatan }\end{array}$} & Badan jalan & $\begin{array}{l}\text { Sirkulasi yang pada suatu saat terjadi } \\
\text { kemacetan }\end{array}$ & ${ }^{2 / 4}$ \\
\hline & & Trotoar Pejalan kaki & Terdapat PKL pada trotoar & $1 / 4$ \\
\hline & & Ruang parkir & Sangat sulit memarkirkan kendaraan & $1 / 4$ \\
\hline & & $\begin{array}{l}\text { Bangunan komersial dan tempat } \\
\text { transit }\end{array}$ & $\begin{array}{l}\text { Pengunjung sering melakukan kegiatan } \\
\text { lain }\end{array}$ & $3 / 4$ \\
\hline 4. & Sosialibilitas & $\begin{array}{l}\text { Bangunan komersial dan tempat } \\
\text { transit }\end{array}$ & $\begin{array}{l}\text { Tidak tersedia bangku untuk melakukan } \\
\text { interaksi sosial. }\end{array}$ & 1 \\
\hline
\end{tabular}

Sumber: Analisis Penulis, 2015

Lampiran 5 Tabel Skoring Tingkat Placemaking Ruang Jalan Koridor Komersial Urip Sumoharjo

\begin{tabular}{|c|c|c|c|c|}
\hline No & Variabel & Sub Variabel & Hasil & Skor \\
\hline \multirow{4}{*}{1.} & \multirow{4}{*}{$\begin{array}{l}\text { Kenyamanan dan } \\
\text { Identitas }\end{array}$} & Badan jalan & Derajat Kejenuhan 0,5 - 0,9 & ${ }^{2} / 4$ \\
\hline & & Trotoar Pejalan kaki & Terdapat trotoar selebar $0,9 \mathrm{~m}$ & $1 / 4$ \\
\hline & & Ruang parkir & Parkir on street & $2 / 4$ \\
\hline & & $\begin{array}{l}\text { Bangunan komersial dan tempat } \\
\text { transit }\end{array}$ & $\begin{array}{l}\text { Rasa betah dari pengguna lebih dari } 60 \\
\text { menit }\end{array}$ & $3 / 4$ \\
\hline \multirow{3}{*}{2.} & \multirow{3}{*}{$\begin{array}{l}\text { Aksesibilitas dan } \\
\text { Tautan }\end{array}$} & Badan jalan & Dilayani moda transportasi umum & 1 \\
\hline & & Trotoar Pejalan kaki & Trotoar dapat dilintasi cukup leluasa & $2 / 3$ \\
\hline & & $\begin{array}{l}\text { Bangunan komersial dan tempat } \\
\text { transit }\end{array}$ & Terdapat shelter untuk tempat transit & 1 \\
\hline \multirow{4}{*}{3.} & \multirow{4}{*}{$\begin{array}{l}\text { Fungsi dan } \\
\text { Kegiatan }\end{array}$} & Badan jalan & $\begin{array}{l}\text { Sirkulasi yang pada suatu saat terjadi } \\
\text { kemacetan }\end{array}$ & $2 / 4$ \\
\hline & & Trotoar Pejalan kaki & Terdapat PKL pada trotoar & $1 / 4$ \\
\hline & & Ruang parkir & Cukup sulit memarkirkan kendaraan & $2 / 4$ \\
\hline & & $\begin{array}{l}\text { Bangunan komersial dan tempat } \\
\text { transit }\end{array}$ & $\begin{array}{l}\text { Pengunjung sering melakukan kegiatan } \\
\text { lain }\end{array}$ & $3 / 4$ \\
\hline 4. & Sosialibilitas & $\begin{array}{l}\text { Bangunan komersial dan tempat } \\
\text { transit }\end{array}$ & $\begin{array}{l}\text { Tidak tersedia bangku untuk melakukan } \\
\text { interaksi sosial. }\end{array}$ & 1 \\
\hline
\end{tabular}

